\title{
Competing Narrative Frames to Account for Random Public Shootings
}

\author{
By Catherine Ann Collins*
}

Two incidents during one week of December 2012 reminded the American public of the potential for massive gun violence even in apparently safe situations. On December 11, a gunman entered an Oregon shopping center and shot three people before his assault rifle jammed. The social media comment posted by a local ABC affiliate - 'Oh dear. Again' ('On social media,' 12/11/12) - reflects the perception that the shooting was part of an ongoing pattern of public violence, a familiar story form. Early headlines label the incident a 'Terror' and 'Shooting rampage'. Despite the low death count, it brought national media attention until three days later when a man, armed with three semi-automatic weapons, killed twenty-six at a Connecticut elementary school. The perception of innocence violated switched media attention to a new terror, but both incidents reveal the same narrative patterns. This essay examines the conventional frames - the narrative strategies - that the media, employ in reporting this form of violence: the first memorializes the victims and reassures the public that violence is an aberration; the second links violence with gun control laws, thus prompting a deliberative impulse to debate gun control. Drawing on media framing and classical rhetorical theory this essay explores the conventional form for addressing random public shootings. The competing narratives create a tension that limits the ability of either to be seen as an appropriate or fitting response to the exigence created by this kind of violence.

\section{Introduction}

Two weeks before Christmas 2012, in a suburban mall in Portland, Oregon, no one expected what a local television reporter described as a "heinous, horrible, tragic crime" ('Gunman, two,' 12/11/12) could occur. On December 11, 2012 at 3:30 p.m. a gunman entered an Oregon shopping center and shot three people before his assault rifle jammed. Sheriff Craig Roberts reported that the shooter fixed his rifle and was able to shoot again ('Gunman, two victims,' 12/11/12). Two of the victims died, Steve Forsyth, 45 and Cindy Yuille, 54; 15-year old Kristina Shevchenko was wounded but survived. The shooter, 22 year-old Jacob Roberts died of self-inflicted gunshot wounds. At the time of the shooting an estimated 10,000 people were in the mall. Hearing

*Professor, Rhetoric and Media Studies, Willamette University, USA.

https://doi.org/10.30958/ajss.1-1-5

doi=10.30958/ajss.1-1-5 
the shots, shoppers and employees ran for exits or secure places within the stores. Others included the mall Santa, simply dropped to the floor because they couldn't tell where the shoots were coming from. Estimates of the number of shots fired vary widely in the accounts of witnesses with estimates as low as 6 or seven and as high as 60. Kira Rowland tells reporters, 'It was just shot after shot. It was terrible. It was like a massacre' ('Gunman, two victims,' 12/12/12). Over 100 officers responded to the call, many within minutes of the first shots being fired.

Clackamas Town Center mall was regarded as a safe place where people spent time shopping, seeing films, and meeting friends. Sheriff Craig Roberts noted, 'For all of us, the mall is supposed to be a place we can all take our families, feel comfortable, this is the holidays. These things are never supposed to happen' ('Gunman, two victims,' 12/11/12). A KATU television viewer posted the following comment, characteristic of many responses during the first few days after the shooting:

Scary times these days. More and more nut jobs going off on innocent people. It should not be this way. How are we, as a nation, a state, and a community to deal with these insane acts of violence that take innocent lives for no reason? What is going on? Why does it seem more and more we have this happening? ('Girl witnesses,' 12/12/12).

The Clackamas shooting joined an expanding list of random public shootings that challenged America's sense of safety by fueling a fear of gun violence. Columbine, Virginia Tech, and an Aurora, Colorado movie theater. The social media comment posted by a local ABC affiliate - 'Oh dear. Again' ('On social media,' 12/11/12) - reflects the perception that the shooting was part of an ongoing pattern of public violence, a familiar story form. Early headlines label the incident a 'Terror' and 'Shooting rampage'. Despite the low death count, the proximity to Christmas and the belief that the mall was a safe place brought national media attention until three days later when a man, armed with three semi-automatic weapons, killed twenty-six at a Connecticut elementary school. The perception of innocence violated by the killing switched media and public attention to a new terror, but both incidents reveal the same narrative patterns.

Random public shootings are not confined to the U.S. Similar mall shootings occurred in Toronto, Canada in 2012, the Netherlands in 2011, and Finland in 2009, to name a few. Examination of the local television news coverage for the week following the Clackamas Town Center shooting serves as a preliminary study of the way news media frame unanticipated, random violence in public spaces.

This essay examines the conventional frames - the narrative strategies that the media employ in reporting this form of violence. It draws on Aristotle's understanding of rhetoric and contemporary media framing theory to explore the implications of creating and reinforcing a conventional form for 
addressing shootings that occur in public spaces. Two fundamental narratives are employed: the first memorializes the victims of such violence and reassures the public that violence is an aberration; the second links violence with gun control laws, thus prompting a deliberative impulse to debate gun control legislation. These competing narratives create a tension that limits the ability of either to be seen as an appropriate or fitting response to the exigence created by this kind of violence.

\section{Theoretical Lens: Narrative Frames as Conventional Form}

Aristotle addresses three kinds of rhetoric: epideictic rhetoric focuses on praise or blame; deliberative rhetoric questions which actions will secure what is best for the city state; and forensic rhetoric, in a trial setting, judges past actions. The response to random public shootings is both epideictic when praising the victims or denigrating the shooters and deliberative when it focuses on legislation that might curtail the instances of public violence.

Aristotle argues that in praising or blaming, epideictic discourse's end is to reflect on the honorable or the shameful (I.3.5). He elaborates the topics specific to epideictic discourse. Since the focus is on what is praiseworthy (or conversely what lacks virtue and hence is blameworthy), it is important to acknowledge things that are, in and of themselves, good. Virtue (arête) is 'defined as an ability for doing good' and is subdivided into 9 qualities (Aristotle, I.9.5). Aristotle concludes that anything that produces virtue is honorable and anything that is contrary to these virtues is shameful. Encomium and vituperation are special forms of epideictic speech and focus on deliberately chosen deeds that reflect a person's habitual character. A person who habitually acts with courage, generosity and self-control will be praised; the person who is selfish, miserly and unjust will be seen as having acted shamefully. Commemorative discourse today may have different senses of virtue (although most are clearly still the substance of contemporary epideictic discourse), but epideictic messages still focus on what individuals or the community have done that is either praiseworthy or blameworthy. The media engages in epideictic discourse when it commemorates the victims of random public shootings and denigrates the shooters.

Aristotle argued that epideictic rhetoric, while centered on the present, could look to the past or the future in exploring what is praiseworthy or blameworthy. Past examples, especially those which are not for the public's welfare may move the rhetor to deliberative discourse in which the focus is on actions that are advantageous or designed to prevent situations and actions that might become disadvantageous to the community. Deliberative discourse assumes that people choose actions and policies that will bring them happiness. Aristotle defines happiness as 'success [eupraxia] combined with virtue or as self-sufficiency [autarkeia] in life or as the pleasant life accompanied with security or as an abundance of possessions and live bodies, with the ability to 
defend and use these things' (I.5.3). In the case of random public shootings happiness revolves around security and what kind of policies need to be enacted to assure a community's safety.

Media stories about public violence are both deliberative and epideictic. Within each type of discourse additional choices about how to frame the discussion are apparent. In addition to a substantive dimension - the claims and evidence, and the who, what, where, when and why of a narrative - messages also have form, a structure and pattern that order the substance and helps the audience make sense of the message. Kenneth Burke contends that a work has form when 'one part of it leads a reader to anticipate another part, to be gratified by the sequence' (1968, p. 124). Every child in hearing 'Once upon a time' knows that what follows may well lead to "and they lived happily ever after.' The child both delights in the story and in his or her anticipation of what inevitably follows those familiar first words. At the broadest level, Burke argues that form may be categorized as progressive, repetitive or conventional; at a narrower level there are minor and incidental forms (e.g. figures of speech and thought) that shape an audience's response to a message. Burke argues that any pattern can be changed into a conventional form that is 'sought for itself,' and that 'the expectations of conventional form may be anterior to the reading' (1968, pp. 126-127). He illustrates the concept in literature by identifying the appeal of literature as different as a Greek tragedy, a sonnet or any one of the steps in Greek oratory. Once recognized and anticipated these forms have appeal in and of themselves. In news accounts conventional form inheres in the narrative frames that journalists employ in telling the story of the events and issues that are the substance of the article.

Entman explains journalistic frames as

selecting and highlighting some facet of events or issues, and making
connections among them so as to promote a particular
interpretation, evaluation, and/or solution. . . . They use words and
images highly salient in the culture, which is to say noticeable,
understandable, memorable, and emotionally charged. (2003, p.
$417)$

For example, news accounts of political campaigns in the United States take for granted the appropriateness of framing the political contest as a horse race. Coverage of the intifada between Israelis and Palestinians whether in the Jerusalem Post or Al-Fajr Jerusalem frequently relies on victimage, land claim, and polarization of self and other frames (Collins \& Clark, 1991). The reader, viewer, or audience for a message recognizes the form, usually accepting the frame without considering the consequences of employing this particular conventional form for organizing and interpreting the events and characters of a particular news event. For example, news accounts that report on environmental conflict often employ a conventional frame that pits environmental concerns against economic costs. In so describing the conflict, 
news accounts make it difficult to see possibilities for simultaneously achieving environmental and economic goals.

In proposing his cascading activation approach to explaining the power of frames, Entman argues that the more habituated the frame among various levels (the Administration, Other Elites, Media, News Frames, and the Public) the less likely it is to be questioned (2003, p. 422). News frames, especially those that are habituated across cultural levels of power, become conventional forms.

Conventional form in news accounts, then, clarifies complex issues and situations and seems to answer what their very existence suggests are the central questions to be addressed. Journalists access a frame that allows them to efficiently and clearly explain an issue/situation, and readers can anticipate the way they will come to understand the story being reported. But news frames, once conventionalized, also hide alternative conceptions of situations, groups, and actions. In this essay I am particularly drawn to how news frames structure the audience's understanding of threatening situations like the Clackamas Town Center shooting.

It seems reasonable to extend Burke's definition of form as anticipation and gratification to explain the inclination to employ conventional form to reassure the return of order in chaotic or stressful situations. This essay examines the conventional form that is employed to report random public shootings, explains how the two predominate frames interact with one another, and poses the question of consequence in mixing the two frames that have become conventional forms in reporting these situations. Although this paper focuses on local television coverage, the frames are also apparent in President Obama's speeches immediately following the incident, in social media responses to the event, and in the way the public responds to questions about their views on what transpired and what the incident says about violence in the nation. That the frames are employed in news accounts, speeches given by elites, in various media forms, and by the public indicates a conventional form activated in conversation about the Clackamas random public shooting; their presence in accounts of the Connecticut school shooting that followed days after Clackamas suggests a conventional form for the broader category of random public shootings.

\section{Framing the Story as Commemorative Discourse}

The first form of story to emerge in news coverage of random public shootings commemorates those who have died, honors those who helped to prevent additional deaths, and blames the shooter for both the deaths and the trauma to others.

The news accounts of the Clackamas Town Center shooting start by praising the virtues of the two victims of the shooting spree. Steve Forsyth is depicted as a 'loving husband, father of two children,' as having 'a vision and a 
belief in others that brought great joy to many people,' and 'a hero to a lot of people' ('Family, friends,' 12/12/12). Kids that he coached said he gave them courage and mentored them effectively. He is repeatedly described as a smart businessman. Former co-workers remember him fondly as a man whose virtues lead to happiness for those around him. Cindy Yuille, a hospice nurse, was seen as 'everybody's friend,' "very caring and put others first,' and capable of 'making everybody laugh' ('Family, friends,' 12/12/12). As a hospice worker helping families deal with end of life issues, Cindy's gentleness and concern for others exemplify the classical virtues, arête. In detailing Steve's and Cindy's virtuous character, and the loss their death brings to family, friends, and co-workers the commemorative news frame makes the random violence that took place that much more shameful.

The shooters in the commemorative news frame can either be blamed because of their habitual bad character (e.g. news accounts of the two men responsible for the Boston Marathon bombing featured their uncle claiming they had always been bad) or they can be cast as disturbed. Initial descriptions of Jacob Roberts cited his aunt who saw him as 'a good boy,' a family friend who told reporters he was ' a popular boy. . the entire family is confused because Roberts "doesn't fit the profile", and a classmate saw him as 'jovial, popular and nice to classmates' ('Mall shooter,' 12/12/12). Other reports included assessments that were less flattering. A KGW story reported friends saying he 'had been acting erratic lately' having quit his job at a sandwich shop and told people he was moving to Hawaii. They quote his aunt as saying, 'he was a normal boy, but had started to show signs of difficulties recently' ('Clackamas shooter,' 12/12/12). In exploring this shooting episode an illness explanation prevails over habitual bad character and thereby reinforces the Clackamas mall shooting as an aberration rather than an indication of societal disorder.

While the story frame inevitably focuses on victims and perpetrators of violence, the conventional frame of an epideictic speech also addresses the broader community, its values, and how the specific loss affects the future of that body. The community in Aristotle's day was responsible for instilling values and courses of action in its citizenry. As Pericles noted in his famous Funeral Oration, Athens provides its citizens with a form of government, laws, recreations, models for productively relating to others, and recognition of virtues in its citizens: 'In sum, I say that our city as a whole is a lesson for Greece' (Thucydides, 1993, p. 43). In turn its citizens sacrifice for Athens. The reciprocal relationship demands commemoration. Pericles explains,

When the power of the city seems great to you, consider then that this was purchased by valiant men who knew their duty and kept their honor in battle, by men who were resolved to contribute the most noble gift to their city: even if they should fail in their attempt, at least they would leave their fine character [arête] to the city. For in giving their lives for the common good, each man won praise for himself that will never grow old; and the monument that awaits them 
is the most splendid - not where they are buried, but where their glory is laid up to be remembered forever, whenever the time comes for speech or action. For to famous men, all the earth is a monument, and their virtues are attested not only by inscriptions on stone at home; but an unwritten record of the mind lives on for each of them, even in foreign lands, better than any gravestone. (Thucydides, 1993, pp. 44-45)

For Pericles and later Aristotle writing about epideictic speech, commemoration is necessary to the individual/polis relationship. While the words may be different the sentiment remains in the contemporary commemoration frame for victims of random public shootings. The local sheriff characterized the victims as heroes, the responders - both law enforcement and medical - as heroic, and the common citizens at the mall who assisted others as heroes in that situation. The headline for KATU television coverage on December 13, 2012 reads, 'Heroes stay with mall shooting victim to the end: "she did not die alone" and another reads, 'Ordinary heroes amid horror' ('Heroes stay,' 12/12/2013). In helping immediately or in subsequent words and actions to memorialize, the citizens of Oregon fulfilled their part of the obligation of community.

Part of the commemoration came in the form of vernacular memorials and official services and vigils to honor the victims and the community. When the mall re-opened several days after the shooting visitors were offered memorial books to remember the events. A sign at the entrance to the mall said 'FOREVER IN OUR HEARTS - 12-11-12'. The media covered these rituals, including a candlelight vigil, attended by several hundred people, that was designed to honor the victims and help the community move forward, 'to remember, to heal, and to begin to hope' ('Vigil honors,' 12/12/12). Participants interviewed by reporters talked about love for one another, respecting the victims, supporting one another, and 'not letting the fears overpower us' ('Vigil honors,' 12/12/12). Ironically the tragedy at Sandy Hook Elementary school only reinforced the tragic events at Clackamas Town Center.

The commemoration frame reinforces the virtues of the community of which the shooting victims and the shooter were a part. In a letter to the editor, Sheriff Roberts concludes,

I believe that no matter how awful the circumstances, no matter how enormous the challenge, we are better equipped to deal with it if we all come together. . . . I hope that as a community and as a nation, we come together around these tragedies and emerge better, stronger and more united for having endured them. ('Clackamas Co. Sheriff,' 12/14/12) 


\section{Deliberations over Gun Control}

Local television coverage quickly moves from the character of the victims, helpers, and the shooter to policies to prevent such violence. At first glance deliberative discussions about gun control legislation appear to be a reasonable response to the exigence of random public shootings; commemoration should invoke deliberation of policies to prevent future occurrences of the same tragedy. Blame for random shootings centers on a lack of gun control legislation in the United States. Congressman Earl Blumenauer, addressing the House of Representatives, opined:

It's hard to have meaningful conversations in a variety of subjects. . .but gun violence is another area in America where it seems we can't have a discussion without delusional claims of overreach and taking away hunting rifles. Congress won't even allow statistics on gun violence to be gathered. And we certainly have made no progress toward closing the "gun-show loophole". ('Rep. Blumenauer,' 12/11/12).

Powerful lobbies come into play with any discussion of gun control, and multiple sides to the debate seem to gravitate to extreme positions, excessive reliance on emotional appeals, and name-calling. The debate over gun control is also characterized by a news frame of political wrangling - whether the right to bear arms extends to semi-automatic weapons, and whether the sides in this political debate have the best interests of the community in mind. The viewer's response that I cited earlier about these being 'scary times' quickly turned to personalized comments about those who carry guns and gun owner rights. Consider three responses: Harry Juku says, 'I'd love to hear how many people were hiding in the dressing rooms even though they were packing heat.' Flyroy responds:

I'm sure there was people 'packing heat' in the back rooms ready to protect themselves and the sheep like you who had pee running down their legs! There are the Wolves, the Sheepdogs and the Sheep in society, and you are the later of the three.

Finally RalphCramden explains,

I carry 24/7 so I have the option to protect myself and my family in a situation like this. That doesn't mean that I think I am Rambo and am going to run through the mall looking for someone with a gun to shoot' ('Girl witnesses,' 12/12/12).

Name-calling does not advance the understanding of either side's position nor does it help others overcome the trauma created by the shootings. 
Four days after the shooting KGW News posts a story headlined, 'Gun stores seeing record setting days' that begins: 'The rush at Portland area gun stores started after the shooting at Clackamas Town Center, but erupted hours after the massacre in Connecticut' ('Gun stores,' 12/15/12). Customers report they fear that gun restrictions are likely to pass so they are buying semiautomatic weapons before prohibitions are in place. The storeowner tells reporter Wayne Havrelly, 'Obviously this rush has to do with what happened in the mall and the school. People have fear that the weapons they want will soon be more difficult to acquire' ('Gun stores,' 12/15/12). KATU reports that $40 \%$ of households in Oregon have guns in them. The sales are attributed to security concerns as well:

They are here because they want to be able to take care of themselves and their families. . . .The tragedies of this past week have really scared people. Now the people asking about concealed carry has escalated greatly. ('Gun store sees,' 12/15/12).

Whether the focus is on increasing gun sales, polarized rhetoric or the unlikelihood of resolving differences on gun control policy, one NPR listener captures the public's frustration with the status of the debate:

Gun control is difficult because the atmosphere has been poisoned by distrust. The two sides have both entrenched themselves in extreme positions and see the middle ground as basically an attempt by the other side to incrementally move the goalposts. . . As long as we leave things up to partisan factions that are mainly motivated by fear, the dysfunctional status quo is likely to remain in place. And the name calling and accusations don't help. (Memmott, 12/12/12)

\section{Competing Frames}

Two news frames predominate and compete in the local television coverage of the shootings at Clackamas Town Center. Early coverage is largely devoted to the commemorative news frame with a focus on a description of the incident that:

- emphasizes character and plot with clearly defined heroes, villains and victims

- focuses on the trauma individuals on the scene and the broader community suffer because of gun violence

- details the rituals of grieving and memorialization and how they restore order and security in a threatening situation 
- reinforces the values and virtues that the community fosters and has displayed in the past, thereby encapsulating the violence as an aberration and not the norm.

Once details of the tragedy have been laid out, the gun control news frame emerges. Gun control legislation is a divisive and long-standing policy issue in the United States. Over the years the debate has followed the same pattern of charge and counter-charge that has led to little understanding of the other side's position and less compromise. Intractable positions make the debate predictable and the likelihood of cooperation and mutually acceptable policy innovations extremely unlikely. Although the gun control news frame appropriately acknowledges the link between commemoration and policy reform, it frequently moves to a focus on political wrangling. In this respect it mirrors a journalistic strategy for framing political issues generally. Regardless of the subject under dispute - whether environmental, economic, or social change (e.g. same sex marriage) - the link between problem and solution is often deemphasized and bickering and power plays are emphasized. Conflict makes for a compelling story, but it does not educate the reader to the issue under debate nor does it emphasize the ways in which the virtues articulated in the commemoration frame might well help a society find mutually acceptable policies for gun control or other deliberative debates. The gun control news frame:

- polarizes the participants by pitting radical opponents against gun control activists, especially those who have been traumatized by gun violence

- details strategies to stalemate the debate; cooperative efforts receive little play

- documents trends in gun sales and incidents of random public shootings

Whether these two frames should be kept separate or whether the deliberations about gun control should wait until after commemoration has occurred remains controversial. The existence of a clash between these two frames is apparent in a KGW-TV report on Obama's speech following the Newtown shooting. The story includes Obama spokesman Jim Carney's response to questions about gun control legislation: "II don't think today is that day" for such a discussion' (Obama calls,' 12/14/12). This statement is followed by Rep. Jerrold Nader, D-N.Y. rebuttal, 'If now is not the time to have a serious discussion about gun control and the epidemic of gun violence plaguing our society, I don't know when is' ('Obama calls,' 12/14/12). The need for commemoration and gun control deliberation is not universally regarded as providing compatible news frames for reporting events like the Clackamas Town Center or Sandy Hook shootings.

The gun control debate is often rancorous and takes the focus away from commemoration, yet it remains an issue that must be discussed. The front page 
of the state's leading newspaper on April 22, 2013 features a story about Donna Matrazzo who tells her experiences with gun violence and concludes, 'This is a very complex issue filled with passionate emotions. We will never get rid of guns or gun violence, but we can save lives' (Francis, p. A1). Her testimony, like that of others who have suffered from gun violence merges commemoration and gun control deliberation. The nature and timing of these competing frames as responses to the exigence of random public shootings warrants further study. This case study of the Clackamas Town Center shooting is a first step toward that larger project. What appears evident at this juncture in the larger project is that the conventionalized form of the gun control frame political wrangling - is not able to advance the concern for minimizing random public shootings in the future. Commemoration without action to prevent further violence seems inadequate, and political wrangling by intransient and polarized groups only suggests that gun control legislation is impossible. The deliberative narrative frame of political wrangling over gun control legislation serves as a palimpsest of America's struggle between gun ownership rights and gun control; a debate rewritten with each new incident of random public shootings. Burke tells us that conventional forms evoke and then gratify our expectations, so if the news frames that we employ conflict, progress in response to the exigence of random public shootings is unlikely. The conventional forms lead us to expect and for many accept the inevitability of more Clackamas Town Center and Sandy Hook episodes of gun-related violence.

\section{References}

Aristotle. (1991). Aristotle on rhetoric: A theory of civic discourse. George A. Kennedy, trans. (New York: Oxford University Press).

Burke, Kenneth. (1968). Counter-Statement. (Berkeley: University of California Press).

Clackamas Co. Sheriff: Letter to the editor. (14 December 2012). KGW.com http://www.kgw.com/home/Clackamas-Co-Sheriff-Letter-to-the-editor-18357 40 61.html\#.

Clackamas shooter had quit job, said goodbye. (12 December 2012). KGW.com http://www.kgw.com/home/Clackamas-gunman-Jacob-Tyler-Roberts-18320321 1.html.

Collins, Catherine A, and Jeanne E. Clark. (1991, Fall). Warring stories in the night: A narrative approach to cultural conflict. Florida Journal of Communication 19: 4555.

Entman, Robert M. (2003). Cascading activation: Contesting the White House's frame after 9/11. Political Communication 20: 415-432.

Family, friends talk about victims of mall shooting. (12 December 2012). KATU.com http://www.katu.com/news/local/Mall-shooting-victim-was-local-marketing-busi ness-owner-183190781.html?print=y.

Francis, James. (22 April 2012). Oregonians talk guns. The Oregonian: A1. 
Girl witnesses gunman shoot woman, then 'aims toward me.' (12 December 2012). KATU.com http://katu.com/news/local/Girl-witnesses-gunman-shoot-womanthen-aims-toward-me-183118051.html?tab=video?print=y.

Gunman, two victims die in Clackamas mall shooting. (11 December 2012). KGW.com http://www.kgw.com/home/Clackamas-Town-Center-shots-fired-183 076991.html.

Gun stores see boom in business after deadly week. (15 December 2012). KATU http://www.katu.com/news/llocal/gun-store-sees=boom-in-business-after-deadlyweek-183660551.html?print=y.

Gun stores seeing record setting days. (15 December 2012). KGW-TV http://www. msnbc.com/id/50211650\#.UMSP-kL6q24.

Heroes stay with mall shooting victim to the end: 'She did not die alone'. (13 December 2012). KATU http://www.katu.com/home/video/Heroes-stay-withmall-shooting-vicitim-to-the-end-she-did-not-die-alone-183370931.html?print=y.

Mall shooter identified as Jacob Tyler Roberts. (12 December 2012). KATU.com http://www.katu.com/news/news/501830-mall-shooter-identified-jacob-tylerroberts.

Memmott, Mark. (12 December 2012). Update: Oregon Gunman identified; killer sent shoppers diving for cover. NPR http://www.npr.org/blogs/thetwo-way/2012 /12/12/167032918/as-shots-rang-out-in-oregon-mall-shoppers-and-santa-doveo for-cover.

Obama calls for action after Conn. Shooting. (14 December 2012). KGW.com http://www.kgw.com/home/183559581.html.

On social media: Terror at the mall. (11 December 2012). KATU.com http://www.katu.com/news/local/On-social-media-Terror-at-the-mall-183113821.

Rep. Blumenauer: 'One is haunted by these events'. (11 December 2012). KATU.com http://www.katu.com/news/local/Rep-Earl-Blumenauer-One-is-haunted-by-theseevents-183184321.html.

Thucydides. (1993). On justice power and human nature: Selections from The History of the Peloponnesian War. Paul Woodruff, trans. (Indianapolis, IN: Hackett Publishing Company).

Vigil honors Clackamas Town Center shooting victims. (15 December 2012). KATU.com http://clackamas.katu.com/news/501927-clackamas-town-center-setreopen-friday-vigil-held-night. 